\title{
ANALISIS PENERAPAN SISTEM PROPOSIONAL DAN SISTEM DISTRIK DALAM PEMILIHAN UMUM UNTUK PENYEDEDERHANAAN SISTEM KEPARTAIAN DI INDONESIA DITINJAU DARI ASAS NEGARA HUKUM
}

\author{
Aminah \\ Fakultas Hukum Universitas Sebelas Maret \\ E-mail:
}

\begin{abstract}
This research aim to get the information on this materials, effort to descript the relation between each another. The study belongs to a normative law research using qualitative approach that is descriptive in nature. Some approaches used to analyse the issue is legislation, historical, and conseptual approaches. To solve the law issue and give prescription about the proper primary and secondary law materials that should be applied as investigating material with the technique of collecting the law materials study documents or literary reviews both printed and electronic (internet) sources are used. The choice for the election sistem is the legislation area, not a constitutionally norms. Its depend the legal politics, and there is not the reason when the pluralism sistem is more preference more than the district sistem. It related with the parliamentary recruitment, and the pluralism can more get the chance for the political party to fine their representative in the House. In order to get the ideal model in relation between party and the election sistem needs the consistence of the legal policy for formulating as public choice.
\end{abstract}

Keywords: election, party, and public policy.

\begin{abstract}
Abstrak
Penelitian ini bertjuan untuk mengetahui hubungan antara sistem pemilihan umum dengan sistem keparataian ditinjau dari asas negara hukum dan pilihan terhadap penetapan sistem pemilihan guna mencapai kebijakan penyederhanaan sistem kepartaian. Penelitian ini termasuk penelitian hukum normatif atau doktrinal dengan metode kualitatif. Sumber data penelitian bahan hukum primer dengan pendekatan perundang-undangan, historis, dan konsep. Analisis data bersifat kualitatif melalui proses reduksi dan penafsiran data serta penarikan kesimpulan. Hasil penelitian menunjukkan bahwa ditinjau dari asas negara hukum keterkaitan sistem pemilu dengan sistem kepartaian dapat diteropong dalam hubungan antara tiga elemen yaitu fungsi, sistem perwakilan dan legalisasi pemilu.Sebelum perubahan UUD 1945 dan sesudah perubahan UUD 1945 ada perubahan pelembagaan pemilu akan tetapi dalam tataran legislasi pemilihan sistem senantiasa tertuju kepada sistem proporsional dengan beraneka macam variasi dan perbedaan elemen-elemen teknis yang terkandung di dalamnya. Sistem proporsional dapat dilanjutkan sebagai kebijakan penetapan sistem pemilu yang cocok untuk Indonesia dengan enam catatan: (i) pengukuhan otonomi daerah dan peningkatan partisipasi lewat ketidakserentaan penyelenggaraan pemilu, (ii) pendisiplinan anggota DPR dan DPRD propinsi dan kota/kabupaten, (iii) restrukturisasi organisasi kepartaian, (iv) penciutan district magnitude, (v) konsistensi penerapan ambang (threshold), dan (vi) demokratisasi partai politik dalam tahap pencalonan. Implikasi dari penelitian adalah ada hubungan yang saling berpengaruh antara sistem pemilihan umum dan sistem kepartaian yang harus diperhatikan dalam kerangka penetapan sistem pemilihan umum. Sementara itu realitas praktis yang menunjukkan konsistensi penetapan sistem pemilihan umum proporsional harus diikuti dengan syarat-syarat tertentu agar dapat menjadi sistem penyederhanaan partai politik.
\end{abstract}




\section{A. Latar Belakang Masalah}

Penelitian ini berfokus kepada dua isu utama yaitu sistem pemilihan umum (pemilu) dan sistem kepartaian. Ada dua sistem pemilihan umum distrik dan proporsional. Di tiap-tiap Negara barangkali pilihannya di antara kedua sistem itu akan tetapi dengan variasi yang tidak sama antara penerapan di satu negara dengan negara yang lain.

Pada intinya, sistem proporsional menghendaki bahwa jumlah wakil rakyat yang duduk di lembaga perwakilan rakyat merupakan potret statistik penduduk. Artinya ada korelasi antara proporsi jumlah penduduk dan wakil yang duduk di lembaga perwakilan. Sementara sistem distrik pada asasnya menegaskan mandat wakil rakyat atas prinsip one man one vote. Dihubungkan dengan sistem kepartaian, sistem proporsional dipandang memiliki proteksi yang kuat untuk memelihara kemajemukan atau jumlah partai politik yang banyak karena perlakuan bahwa tidak ada suara yang tidak sah dan ada kemungkinan tiaptiap partai politik di suatu daerah pemilihan mampu menempatkan wakilnya di lembaga perwakilan, beberapa pun jumlahnya. Sementara sistem distrik menegasikan hal itu karena the winners takes all, artinya sebuah mayoritas sederhana perolehan suara akan menyebabkan hanya satu partai politik yang mampu menempatkan wakilnya di lembaga perwakilan rakyat. Dengan sistem ini, sudah pasti banyak suara yang hangus dan pastinya akan menyebabkan partai politik mau tidak mau harus berkoalisi daripada tidak mempunyai wakil sama sekali.

Setelah reformasi, pemilihan umum tahun 1999 diikuti oleh 48 partai politik, cermin ledakan partisipasi rakyat setelah hampir tiga dasawarsa di bawah pemerintahan otoritarian Orde Baru. Pada pemilihan umum selanjutnya, yaitu pada tahun 2004, peserta pemilihan umum menyusut menjadi 24 partai politik. Kondisi inilah yang kemudian mendorong suarasuara masyarakat yang menyadari adanya korelasi antara sistem pemilihan umum (yang antara lain memasyarakatkan batas ambang suara tertentu atau electoral threshold) dengan kehendak menyederhanakan sistem kepartaian. Tetapi, menjelang Pemilihan Umum 2009, Dewan
Perwakilan Rakyat (DPR) menolak aspirasi itu dan kemudian justru melaksanakan parlemantairy threshold sebagai titik batas keikutsertaan partai politik dalam pemilihan umum, sehingga peserta pemilihan umum 2009 meningkat menjadi 32 partai politik di tigkat nasional dan enam partai politik lokal di Aceh. Dari pemilihan umum satu waktu ke waktu yang lain, sistem pemilihan yang digunakan sama yaitu sistem proporsional yang bervariasi antara proporsional terbuka dan proporsional tertutup, walaupun wacana penerapan sistem distrik juga mengemuka tapi tidak pernah menjadi kebijakan resmi dalam peraturan perundang-undangan pemilihan umum.

Penelitian ini menganggap penting kajian korelasi sistem pemilihan umum dan sistem kepartaian. Atas dasar uraian latar belakang masalah tersebut, maka dilakukan penelitian yang berjudul "Analisis Penerapan Sistem Proporsional dan Sistem Distrik dalam Pelaksanaan Pemilihan Umum untuk Penyederhanaan Sistem Kepartaian di Indonesia Ditinjau dari Asas Negara Hukum."

Pertanyaan yang mendasar adalah apakah penerapan sistem sistem pemilihan umum distrik dan proporsional dapat menjadi sarana untuk penyerdehanaan partai politik, sebagai sebuah problem dalam ketatanegaraaan Indonesia.

\section{B. Metode Penelitian}

Penelitian ini merupakan peneltian hukum normatif, dengan menggunakan pendekatan perundang-undangan dan pendekatan konsep. Teknik pengumpulan data dilakukan dengan cara mengidentifikasikan isu hukum serta mengeliminasikan hal-hal yang tidak relevan dengan topik penelitian melalui pengumpulan bahan-bahan hukum, melakukan telaah atas isu hukum yang diajukan, menarik kesimpulan, dan memberikan preskripsi. Analisis bahan hukum didasarkan pada prinsip konsistensi logis antara asas-asas hukum baku yang terkait dengan permasalahan yang diteliti dan dilihat kemungkinan adanya penyimpangan-penyimpangan asas.

\section{Hasil Penelitian dan Pembahasan}

1. Konseptualisasi Negara Hukum 
$\begin{array}{cccr}\text { Arti } & \text { negara } & \text { hukum } & \text { pada } \\ \text { hakikatnya } & \text { berakar dari } & \text { konsep } \\ \text { kedaulatan } & \text { hukum } & \text { yang } & \text { pada } \\ \text { prinsipnya } & \text { menyatakan } & \text { bahwa }\end{array}$ kekuasaan tertinggi di dalam suatu negara adalah hukum, oleh sebab itu seluruh alat perlengkapan negara apapun namanya termasuk warga negara harus tunduk dan patuh serta menjunjung tinggi hukum tanpa kecuali (Hestu C.Handoyo, 2003:12).

Negara hukum merupakan gagasan modern yang multiperspektif dan selaku aktual. Istilah Negara hukum merupakan terjemahan langsung dari istilah rechtsstaat. Dalam memberikan pengertian mengenai gagasan negara hukum ini, setiap orang dapat memberikan bobot penilaian yang berlebihan baik terhadap kata "negara" maupun kata "hukum". Setidaknya terdapat 2 (dua) tradisi besar gagasan Negara hukum di dunia, yaitu negara hukum dalam tradisi Eropa Kontinental yang disebut rechtsstaat dan Negara Hukum dalam tradisi Anglo Saxon yang disebut dengan rule of Law (Moh. Kusnardi dan Harmaily Ibrahim, 1976:8).

Menurut Jimly Asshiddiqie, baik konsep rule of Law maupun rechtsstaat selalu mengalami perkembangan dari waktu ke waktu sehingga pengertian keduanya pada masa kini mempunyai beberapa perbedaan dengan pengertian keduanya pada masa lalu (Jimly Asshiddiqie 2006: 4). Syarat-syarat dasar bagi pemerintahan yang demokratis di bawah konsep Rule of law yang adalah (A. Ahsin Thohari,2004:49) :

a. Perlindungan konstitusional

b. Kekuasaan kehakiman yang bebas dan tidak memihak

c. Pemilihan umum yang bebas

d. Kebebasan menyatakan pendapat

e. Kebebasan berserikat dan beroposisi

f. Pendidikan kewarganegaraan Menurut Bagir Manan dan Kuntana Magnar, negara hukum mengandung pengertian kekuasaan dibatasi oleh hukum dan sekaligus menyatakan bahwa hukum adalah supreme dibandingkan dengan alat kekuasaan yang ada (Bagir Manan dan Kuntana Magnar 1993: 128). Hal ini berarti bahwa ajaran negara berdasarkan atas hukum mengandung esensi bahwa hukum adalah supreme dan kewajiban bagi setiap penyelenggara negara atau pemerintahan untuk tunduk pada hukum (subject to law). Tidak ada kekuasaan yang sewenang-wenang (arbitrary power) atau penyalahgunaan kekuasaan (misuse of power) (Bagir manan, 1999: 11).

Negara sebagai pencipta dan penegak hukum, maka di dalam segala kegiatannya harus tunduk pada hukum yang berlaku (due process of law). Secara garis besar dapat dikatakan bahwa pengertian negara hukum adalah negara yang segala kegiatannya dalam rangka penyelenggaraan negara didasarkan pada ketentuan peraturan hukum yang berlaku. Menurut Immanuel Kant sebagaimana dikutip Budiyanto, ada empat prinsip yang menjadi ciri negara hukum, yaitu: (Immanuel Kant dalam Budiyanto, 1999: 51) :

a. pengakuan dan jaminan atas hakhak asasi manusia;

b. pemisahan kekuasaan untuk menjamin hak-hak asasi manusia;

c. pemerintahan berdasarkan hukum, dan

d. pengadilan untuk menyelesaikan masalah yang timbul sebagai akibat pelanggaran hak asasi manusia.

2. Konseptualisasi Partai Politik

Dalam demokrasi, partai berada dan beroperasi pada suatu sistem kepartaian tertentu. Setiap partai merupakan bagian dari sitem kepartaian yang diterapkan disuatu negara. Dalam suatu sistem tertentu, partai berinteraksi dengan sekurangkurangnya satu partai lain atau lebih sesuai dengan konstruksi relasi regulasi yang diberlakukan. Sistem kepartaian memberikan gambaran tentang struktur persaingan diantara sesama partai politik dalam upaya meraih kekuasaan dalam pemerintahan. 
Untuk melihat sistem kepartaian suatu negara, ada dua pendekatan yang dikenal secara umum. Pertama, melihat partai sebagai unit-unit dan sebagai satu kesatuan yang terlepas dari kesatuan-kesatuan lain. Pendekatan numerik ini pernah dikembangkan Maurice Duverger, ilmuwan politik kebangsaan Prancis. Menurut Duverger, sistem kepartaian dapat dilihat dari pola perilaku dan interaksi antar sejumlah partai dalam sistem politik, yang dapat digolongkan menjadi tiga unit, yakni sistem partai tunggal, sistem dwi partai, sistem multipartai (Agung Gunandjar Sudarsa, 2010:1)

Menurut Jimly Asshiddiqie, partai politik adalah asosiasi warga negara dan karena itu berstatus sebgai badan hukum (rechtspersoon). Akan tetapi, sebagai badan hukum, partai politik itu tidak beranggotakan badan hukum yang lain. Yang dapat menjadi anggota badan hukum partai politik adalah perorangan warga negara sebagai natuurlijke persoons. Status partai politik sebagai badan hukum itu sangat penting dalam hubungan dengan kedudukan partai politik itu sebagai subyek dalam lalu lintas hukum (Jimly Asshiddiqie 2006: 69). Pada sisi lain, Haryanto mengidentifikasi dua lagi pemahaman partai politik yang didasarkan kepada sejumlah pendapat sarjana terkemuka, yaitu:

a. Partai politik merupakan persekutuan dari individuindividu yang diorganisa-sikan untuk memilih, mempengaruhi, dan mengontrol jabatan-jabatan politik; dan

b. Partai politik merupakan suatu perkum-pulan yang bermaksud mengontrol jalannya roda pemerintahan dengan cara menempatkan para anggotanya pada jabatan-jabatan pemerintahan. (Haryanto 1984: 8-9).

3.Konseptualisasi Sistem Pemilihan Umum.

Konseptualisasi sistem pemilihan umum di sini terkait dengan pengisian jabatan lembaga perwakilan rakyat. Pemilihan umum lazimnya dikaitkan dengan fungsi pelaksanaan kedaulatan rakyat.

Kedaulatan menurut Pasal 1 ayat (2) Undang-Undang Dasar Negara Republik Indonesia Tahun 1945 berada ditangan rakyat dan dilaksanakan menurut UUD 1945. Melaksanakan kedaulatan itu bagi rakyat adalah dengan cara menentukan atau turut menentukan sesuatu kebijaksanaan kenegaraan tertentu yang dapat dilakukan sewaktu-waktu menurut tata cara tertentu. Misalnya, rakyatlah yang harus menentukan atau turut menentukan atau memutuskan apakah suatu perbuatan tertentu akan ditetapkan sebagai suatu bentuk kejahatan yang dilarang atau tidak melalui wakil-wakil rakyat.

Untuk menentukan orang yang akan menduduki wakil rakyat yang akan duduk di DPR, DPD, dan DPRD maka rakyat sendirilah yang secara langsung harus menentukan melalui pemilihan umum yang bersifat langsung. Namun metode penyaluran pendapat rakyat yang berdaulat dalam sistem demokrasi Indonesia ada yang bersifat langsung (direct democracy) dan ada pula yang bersifat tidak langsung atau (indirect democracy) atau biasa juga disebut sebagai sistem demokrasi perwakilan (representative democracy).

Tujuan penyelenggaran pemilu (general election) itu pada pokoknya dapat dirumuskan ada empat, yaitu: (Jimlly Asshiddiqie; 2007:754)

a. Untuk memungkinkan adanya suatu peralihan kepemimpinan pemerintahan secara tertib dan damai;

b. Untuk memungkinkan terjadinya pergantian pejabat yang akan mewakili kepentingan rakyat di lembaga perwakilan;

c. Untuk melaksakan prinsip kedaulatan rakyat, dan;

d. Untuk melaksanakan prinsip hakhak asasi warga negara.

Menurut Andrew Haywood yang dikutip oleh Sigit Pamungkas 
fungsi pemilu terumuskan dari dua perspektif, yaitu (Andrew Haywood dalam Sigit Pamungkas, 2009:4-6) :

1). Perspektif Bottom up, fungsi pemilu dilihat sebagai sarana politisi dapat dipanggil untuk bertanggung jawab dan ditekan untuk mengantarkan bagaimana merefleksikan kebijakan publik, yaitu :
(a) Sebagai sarana rekruitmen politisi;
(b) Membentuk pemerintahan; dan
(c) Sarana membatasi perilaku dan kebijakan pemerintah.

2). Perspektif Top Down, fungsi pemilu dilihat sebagai sarana elite melakukan control terhadap rakyat agar tetap diam/bergerak, dapat ditundukkan dan akhirnya dapat diperintah, yaitu:
(a) Memberi legitimasi kekuasaan;
(b) Sirkulasi dan penguatan elite;
(c) Menyediakan perwakilan; dan
(d) Sarana pendidikan politik. Masih terkait dengan unsur sistem pemilu, di dalam praktik pengaturan kadang-kadang juga diterapkan mekanisme threshold yaitu tingkat minimal dukungan yang harus diperoleh sebuah partai untuk mendapatkan perwakilan. Batas minimal itu umumnya diwujudkan dalam prosentase hasil pemilu dan besarannya tidak sama untuk setiap negara (Sigit Pamungkas, 2009: 19). Jika pengaturan threshold itu dituangkan ke dalam sebuah pengaturan perundang-undangan, maka dikenal sebagai legal threshold. Tetapi praktik juga menunjukkan, bahwa legal threshold berkembang dari sekedar batas minimal dukungan yang harus diperoleh partai untuk mendapatkan perwakilan di parlemen (parlementary threshold), menjadi batas minimal yang harus diperoleh oleh partai sebagai syarat untuk dapat mengikuti pemilu pada periode berikutnya (electoral threshold).
Setelah reformasi 1998, pemilu sudah dilaksanakan sebanyak 3 kali, yaitu berturut-turut pada 1999, 2004, dan 2009. Pemilu 1999, dilaksanakan dengan UU No. 3 Tahun 1999 tentang Pemilu. Peserta Pemilu adalah partai politik, dengan memenuhi persyaratan-persyaratan tertentu. Dari 148 partai politik yang terdaftar di Departemen Kehakiman,sebanyak 48 partai politik dinyatakan memenuhi syarat untuk mengikuti pemilu. Untuk mengisi 462 kursi anggota DPR, sistem yang dipakai adalah proporsional berdasarkan stelsel terdaftar. Pada sistem ini peserta pemilu mendapatkan alokasi kursi berdasarkan proporsi suara yang diperolehnya. Penentuan sisa suara ditetapkan dengan mengacu kepada sisa suara terbesar. Partai-partai juga boleh melakukan stembus accord. Daerah pemilihan DPR adalah propinsi dengan ketentuan setiap kabupaten/kota minimal mendapatkan 1 (satu) kursi. Jumlah kursi DPR untuk setiap daerah pemilihan didasarkan pada jumlah penduduk.

Pemilih memilih tanda gambar partai. Daftar calon tidak ditulis dalam surat suara, tetapi diumumkan terbuka di tiap Tempat Pemungutan Suara (TPS). Partai politik dapat mengajukan calon sebanyak 2 (dua) kali atau 200\% dari jumlah kursi yang ditetapkan.

Penentuan calon terpilih dari tiap partai politik merujuk suara terbanyak dari daerah pemilihan di mana seseorang dicalonkan. Dengan demikian, meski seorang calon berada di urutan terbawah dari daftar calon, kalau dari daerahnya partai mendapatkan suara terbesar, maka dialah yang terpilih. Cara ini menjadikan pemilih adalah yang menentukan terpilihnya seseorang menjadi calon jadi. Peranan partai politik hanya sebatas menominasikan kandidat, menentukan terpilihnya calon jadi.

Kemudian, pemilu tahun 2004 dilaksanakan berdasarkan UU No. 12 Tahun 2003 tentang Pemilu. Peserta pemilu DPR adalah 24 partai dengan 
rincian sebanyak 6 partai politik (PDIP, Golkar, PPP, PKB, PAN, dan PBB) ditetapkan otomatis sebagai peserta karena memenuhi electoral threshold dan 18 partai politik baru.

Terdapat 550 kursi DPR yang diperebutkan. Sistem pemilu yang dipakai adalah sistem perwakilan proporsional terbuka. Secara teoritik, sistem itu menjadikan partai politik akan memperoleh kursi sebanding dengan perolehan suara (Sigit Pamungkas, 2009: 113). Pada pemilu 2004 ini, daerah pemilihan anggota DPRadalah propinsi atau bagianbagian propinsi.

Dalam pengajuan calon anggota DPR, setiap partai politik dapat mengajukan calon sebanyakbanyaknya $120 \%$ dari jumlah kursi yang ditetapkan pada setiap daerah pemilihan. Dalam kertas suara, selain mencantumkan nama dan tanda gambar partai, juga disertakan caftar calon anggota DPR dari setiap partai berdasarkan nomor urut. Cara penyuaraan (balloting) yang dipakai adalah dengan memilih tanda gambar saja, dan/atau tanda gambar, sekaligus nama calon legislatif (caleg). Dalam penyuaraan ini, suara dianggap tidak sah, apabila nama caleg saja. Penyuaraan dinyatakan sah apabila pemilih memilih tanda gambar partai dan nama caleg secara bersamaan. Pada Pemilu 2009, DPR melakukan perubahan regulasi yang terkait dengan penyelenggaraan pemilu. Perubahan itu dimaksudkan untuk dapat menjawab persoalanpersoalan mendasar yang muncul dalam pemilu sebelumnya. Sejumlah peraturan perundang-undangan baru ditetapkan untuk menjadi landasan hukum dalam rangka penyelenggaraan pemilihan umum, yaitu:

a. UU No. 22 Tahun 2007 tentang Penyelenggara Pemilihan Umum

b. UU No. 2 Tahun 2008 tentang Partai Politik

c. UU No. 10 Tahun 2008 tentang Pemilihan Umum Anggota DPR, DPD, dan DPRD; dan

d. UU No. 12 Tahun 2008 tentang Perubahan UU No. 32 Tahun
2004 tentang Pemerintah Daerah (terkait dengan syarat pilkada melalui calon perseorangan).

Pada tingkat nasional peserta pemilu (2009) berjumlah 38 partai politik. Menurut UU. No. 10 Tahun 2008, jumlah kursi yang diperebutkan untuk DPR adalah 560 kursi (Pasal 21). Secara prinsip sistem yang dipakai adalah sistem proporsional, meskipun dengan beberapa modifikasi. Pasal 22 ayat (1) menyatakan daerah pemilihan anggota DPR adalah provinsi atau bagian provinsi. Sehingga dapat diartikan bahwa konsep representasi atau daerah pemilihan yang dipakai adalah propinsi atau bagian-bagian propinsi Untuk pemilu DPR, district magnitude adalah antara 3-10 kursi. Hal tersebut sesuai dengan Pasal 22 ayat (2) yang menyatakan bahwa jumlah kursi setiap daerah pemilihan anggota DPR paling sedikit 3 (tiga) kursi dan paling banyak 10 (sepuluh) kursi.

Pada kandidasi, setiap partai politik dapat mengajukan sebanyakbanyaknya $120 \%$ jumlah kursi yang ditetapkan pada setiap daerah pemilihan (Pasal 54). Pada setiap 3 (tiga) nama calon, partai harus menyertakan sekurang-kurangnya 1 calon perempuan (kuota 30\% dalam pencalonan, Pasal 55 ayat (2). Dengan sistem ini, andaikata sebuah daerah pemilihan terdapat 10 kursi yang diperebutkan dan partai mengajukan daftar calon dalam jumlah maksimal, yaitu $120 \%$ dari 10 kursi, sama dengan 12 calon, maka partai politik harus menyertakan 4 orang calon perempuan di setiap 3 (tiga) nama calon. Cara menempatkan calon perempuan bisa di setiap kelipatan tiga ataupun dua.

Dalam format kertas suara, dicantumkan nama dan tanda gambar partai serta daftar calon anggota DPR dari setiap partai berdarakan nomor urut berdasarkan Pasal 143 ayat (1) yang menyatakan bahwa surat suara sebagaimana dimaksud dalam Pasal 142 ayat (1) huruf $b$ untuk calon anggota DPR, DPRD provinsi, dan 
DPRD kabupaten/kota memuat tanda gambar partai politik, nomor urut partai politik, nomor urut calon, dan nama calon tetap partai politik untuk setiap daerah pemilihan.

Cara penyuaraan (balloting) yang dipakai adalah menandai salah satu diantara gambar partai politik, nomor urut calon atau nama calon. Suara tidak sah jika memberi tanda lebih dari satu kali pada kertas suara. Hal ini sesuai dengan pasal 153 yang bunyi lengkapnya adalah sebagai berikut:

Pasal 153

(1) Pemberian suara untuk Pemilu anggota DPR, DPD, DPRD provinsi, dan DPRD kabupaten/kota dilakukan dengan memberikan tanda satu kali pada surat suara;

(2) Memberikan tanda satu kali sebagaimana dimaksud pada ayat (1) dilakukan berdasarkan prinsip memudahkan pemilih, akurasi dalam penghitungan suara, dan efisien dalam penyelenggaraan Pemilu; dan

(3) Ketentuan lebih lanjut tentang tata cara memberikan tanda diatur dengan peraturan KPU.

Pada pemilu 2009, UU No. 10 Tahun 2008 memakai 2 (dua) threshold. Pertama, electoral threshold, yaitu syarat partai untuk dapat ikut serta dalam pemilu sebelumnya, sebesar 3\% suara Pasal 315 yang dengan jelas menyebutkan bahwa :

"Partai Politik Peserta Pemilu tahun 2004 yang memperoleh sekurang-kurangnya 3\% (tiga perseratus) jumlah kursi DPR atau memperoleh sekurang-kurangnya 4\% (empat perseratus) jumlah kursi DPRD provinsi yang tersebar sekurang-kurangnya di $\quad 1 / 2$ (setengah) jumlah provinsi seluruh Indonesia, atau memperoleh sekurang-kurangnya 4\% (empat perseratus) jumlah kursi DPRD kabupaten/kota yang tersebar sekurang-kurangnya di $\quad 1 / 2$ (setengah) jumlah kabupaten/kota seluruh Indonesia, ditetapkan sebagai Partai Politik Peserta Pemilu setelah Pemilu tahun 2004"

Kedua, parliamentary threshold, yaitu syarat partai politik untuk dapat diikutsertakan dalam penghitungan kursi DPR dengan besaran 2,5\%. Partai-partai yang perolehan suaranya tidak mencapai $2,5 \%$ tidak dapat menempatkan wakilnya di DPR. Ketentuan parliamentary threshold ini dijadikan dasar untuk menentukan partai-partai yang tidak sah diikutsertakan dalam penentuan perolehan kursi DPR. Hal tersebut sesuai dengan penjelas pasal 205 yang bunyi lengkapnya adalah sebagai berikut:

Pasal 205

(1) Penentuan perolehan jumlah kursi anggota DPR Partai Politik Peserta Pemilu didasarkan atas hasil penghitungan seluruh suara sah dari setiap Partai Politik Peserta Pemilu yang memenuhi ketentuan pasal 202 di daerah pemilihan yang bersangkutan;

(2) Dari hasil penghitungan seluruh suara sah sebagaimana dimaksud pada ayat (1) ditetapkan angka BPP DPR.;

(3) Setelah ditetapkan angka BPP $D P R$ dilakukan penghitungan perolehan kursi tahap pertama dengan membagi jumlah suara sah yang diperoleh suatu Partai Politik Peserta Pemilu di suatu daerah pemilihan dengan BPP DPR;

(4) Dalam hal masih terdapat sisa kursi dilakukan penghitungan perolehan kursi tahap kedua dengan cara membagikan jumlah sisa kursi yang belum terbagi kepada Partai Politik Peserta Pemilu yang memperoleh suara sekurangkurangnya $50 \%$ (lima puluh perseratus) dari BPP DPR;

(5) Dalam hal masih terdapat sisa kursi setelah dilakukan 
penghitungan tahap kedua, maka dilakukan penghitungan perolehan kursi tahap ketiga dengan cara seluruh sisa suara Partai Politik Peserta Pemilu dikumpulkan di provinsi untuk menentukan BPP DPR yang baru di provinsi yang bersangkutan;

(6) BPP DPR yang baru di provinsi yang bersangkutan sebagaimana dimaksud pada ayat (5) ditetapkan dengan membagi jumlah sisa suara sah seluruh Partai Politik Peserta Pemilu dengan jumlah sisa kursi; dan

(7) Penetapan perolehan kursi Partai Politik Peserta Pemilu sebagaimana dimaksud pada ayat (5) dilakukan dengan cara memberikan kursi kepada partai politik yang mencapai BPP DPR yang baru di provinsi yang bersangkutan.

Perhitungan perolehan kursi partai untuk DPRD tidak berbeda dengan Pemilu 2004. Sementara itu, pada penentuan perolehan kursi DPR terdapat modifikasi, yaitu menggunakan sistem sisa suara terbesar (largest remainder) varian Hare dengan bersyarat. Penentuan perolehan kursi partai dilakukan setelah pengurangan suara dari partaipartai yang tidak memenuhi parliamentary threshold, dan sisa kursi yang belum habis dibagi pada perhitungan tahap pertama di sebuah daerah pemilihan diberikan kepada partai yang mendapatkan suara lebih dari 50\% dari Bilangan Pembagi Pemilih (BPP).

Jika masih terdapat sisa kursi di sebuah daerah pemilihan, tetapi perolehan suara sisa partai tidak mencapai 50\% BPP, maka suara partai diakumulasikan di tingkat propinsi untuk dibuat BPP baru guna menentukan partai yang berhak mendapatkan kursi sebagaimana yang diatur dalam Pasal 207 yang menyatakan bahwa dalam hal masih terdapat sisa kursi yang belum terbagi sebagaimana dimaksud dalam pasal 206 dan sisa suara Partai Politik Peserta Pemilu sudah terkonversi menjadi kursi, maka kursi diberikan kepada partai politik yang memiliki akumulasi perolehan suara terbanyak secara berturut-turut di provinsi yang bersangkutan.

Adapun penentuan calon jadi di sebuah partai politik yang memperoleh kursi parlemen adalah didasarkan kepada nomor urut bersyarat, kecuali yang bersangkutan memperoleh suara $100 \%$ BPP. Apabila seseorang memperoleh suara $100 \%$ BPP, maka secara langsung ditetapkan menjadi calon jadi. Jika suara calon tidak mencapai $100 \%$ BPP, maka seorang calon harus memperoleh 30\% dari BPP untuk ditetapkan menjadi calon terpilih. Jika tidak ada calon yang mendapat 30\% BPP, maka ditetapkan berdasarkan nomor urut murni. Hal tersebut diatur berdasarkan pasal 204 yang bunyi lengkapnya adalah sebagai berikut:

Pasal 214
Penetapan calon terpilih
anggota DPR, DPRD Provinsi,
dan DPRD kabupaten/kota
dari Partai Politik Peserta
Pemilu didasarkan pada
perolehan kursi Partai Politik
Peserta Pemilu di suatu daerah
pemilihan, dengan ketentuan:
a. calon terpilih anggota
DPR, DPRD provinsi, dan
DPRD kabupaten/kota
ditetapkan berdasarkan
calon yang memperoleh
suara sekurang-kurangnya
30\% (tigar puluh
perseratus) dari BPP;
dalam hal calon yang
memenuhi ketentuan huruf
a jumlahnya lebih banyak
daripada jumlah kursi
yang diperoleh partai
politik peserta pemilu,
maka kursi diberikan
kepada calon yang
memiliki nomor urut lebih
kecil di antara calon yang
memenuhi ketentuan
sekurang-kurangnya $30 \%$


(tiga puluh perseratus) dari BPP;

c. dalam hal terdapat dua calon atau lebih yang memenuhi ketentuan huruf a dengan perolehan suara yang sama, maka penentuan calon terpilih diberikan kepada calon yang memiliki nomor urut lebih kecil di antara calon yang memenuhi ketentuan sekurang-kurangnya 30\% (tiga puluh perseratus) dari BPP, kecuali bagi calon yang memperoleh suara 100\% (seratus perseratus) dari BPP;

d. dalam hal calon yang memenuhi ketentuan huruf a jumlahnya kurang dari jumlah kursi yang diperoleh partai politik peserta pemilu, maka kursi yang belum terbagi diberikan kepada calon berdasarkan nomor urut;dan

e. dalam hal tidak ada calon yang memperoleh suara sekurang-kurangnya 30\% (tiga puluh perseratus) dari BPP, maka calon terpilih ditetapkan berdasarkan nomor urut.

Hasil studi menunjukkan sistem proporsional selalu menjadi pilihan dalam penyelenggaraan pemilu dengan anekarupa modifikasi. Kecenderungan semenjak Orde Baru juga menunjukkan bahwa pengubahan, penyempurnaan, dan penggantian regulasi selalu menjadi pilihan ketika pemilu pertama era reformasi yaitu kebijakan sistem proporsional dilanjutkan pada pemilu pertama era reformasi yaitu Pemilu 1999. diikuti 48 partai politik peserta pemilu, hanya 5 partai yang mampu memperoleh lebih dari 3\% suara rakyat. Ada 27 partai yang perolehan suaranya tidak mampu memperoleh kursi di DPR dan 10 partai hanya mampu memperoleh 1 kursi di parlemen. Sistem proporsional memang dipilih dan dianggap sebagai legitimasi untuk menampung euphoria demokrasi serta dianggap member ruang dan waktu kepada partai politik baru.

Kohesivitas sistem pemilu dan sistem kepartaian tidak berlanjut dalam mengelola hasil pemilu. Terciptanya pluralisme sederhana menciptakan kekuatan partai politik yang besar dalam menentukan stabilitas pemerintahan. Segera tampak: fragmentasi partai politik mulai timbul dan partai politik baru dengan mudah terbentuk jika tidak puas dengan partai induk. Disiplin parlemen longgar karena recall dihapus dan fenomena "menyeberang" partai bagi wakil rakyat mulai muncul. Pemilu 2004 melanjutkan sistem proporsional tetapi dengan sistem daftar terbuka. Balloting ditentukan dengan memberikan suara untuk partai politik atau partai politik dengan daftar calon preferensi. Tetapi jika hanya memberikan tanda untuk daftar calon dianggap tidak sah. Dari sisi kedaulatan rakyat, otonomi daerah, dan sistem kepartaian, ditemukan ketidakserasian antar UUD 1945, Perundang-undangan kepartaian dan pemilu, dan Kitab Undang-Undang Hukum Pidana (KUHP). Ketika UUD 1945 mengikuti demokrasi berdasarkan prinsip keterwakilan, maka undang-undang menuntut supaya wakil rakyat, khususnya DPR, direkrut dari partai politik peserta pemilu dan ditetapkan lewat pemilu. Hal ini diatur dalam Pasal 22E ayat (3) UUD 1945 yang menyatakan bahwa Peserta pemilihan umum untuk memilih anggota Dewan Perwakilan Rakyat dan anggota Dewan Perwakilan Rakyat Daerah adalah partai politik. Selain itu pasal 5 ayat (1) dan (2) UU No.10 Tahun 2008 jo Pasal 65 UU No.12 Tahun 2003 juga menyatakan hal yang sama sebagai berikut:

(1) Pemilu untuk memilih anggota DPR, DPRD provinsi, dan DPRD kabupaten/kota dilaksanakan 
dengan sistem proporsional terbuka.

(2) Pemilu untuk memilih anggota DPD dilaksanakan dengan sistem distrik berwakil banyak.

Caleg partai merupakan hasil seleksi demokratis dan terbuka sesuai dengan aturan internal partai politik. Tetapi, legislasi tidak menuntut "bukti" bahwa penetapan caleg telah dipilih secara demokratis dan terbuka tidak menjadi persyaratan yang diminta oleh KPU.

Pilihan kepada sistem proporsional masih berlanjut pada pemilu 2009 tetapi dengan modifikasi balloting, yaitu menandai salah satu diantara gambar partai politik, nomor urut calon, atau nama calon. Suara tidak sah jika memberi tanda lebih dari satu kali pada kertas suara. Ketentuan ini tidak memberikan batasan yang jelas karena satu suara tidak jelas sasarannya, apakah kepada calon atau kepada partai politik? Pemberian suara dan cara menghitungnya bukan berdasarkan OPOVOV (one person, one vote, one value), tetapi OPOV (one persone, one vote) dengan kemungkinan 2 suara. Ketidak pastian pemberian suara, untuk caleg atau partai politik, tidak dapat disebut sistem proporsional murni terbuka. Pembelahan perhitungan kepada partai politik atau calon ini melambankan rekapitulasi suara. Preferensi pemilih kepada calon terganjal oleh pemberian suara kepada partai politik. Bahkan melalui Surat Edaran KPU No. 676 Tahun 2009, KPU mengijinkan surat suara dari daerah pemilihan lain untuk dicentang pada kolom partai politik. Tetapi model penghitungan perolehan kursi DPR akan cenderung menguntungkan partai besar, sementara partai-partai kecil dan menengah menjadi terpinggirkan. Sebaliknya, dalam hal pemilihan
DPRD, suara partai kecil dan menengah menjadi superior, karena mereka akan mendapatkan kursi dari alokasi di perhitungan kedua seperti yang umum terjadi dalam Pemilu 2004.

\section{Simpulan}

Penerapan sistem proporsional dan sistem distrik dalam kaitannya dengan kebutuhan penyederhanaan sistem kepartaian ditinjau dari perspektif negara hukum dapat disimpulkan sebagai berikut.

a. Pada asasnya sistem pemilu merupakan seperangkat metode atau aturan untuk mentransfer suara pemilih ke dalam satu lembaga perwakilan dan memiliki sejumlah unsur antara lain: (i) penyuaraan (balloting); (ii) besaran distrik (district magnitude); (iii) pembuatan batas-batas representasi; (iv) formula pemilihan (electoral formula); (v) ambang batas (threshold); dan (vi) jumlah kursi di lembaga perwakilan rakyat; dan

b. Sistem pemilu pada garis besarnya dapat dibagi menjadi sistem proporsional, sistem distrik, dan sistem campuran, yang mana tidak akan pernah dapat ditetapkan secara pasti sistem manakah yang paling tepat diterapkan, karena bagi suatu negara yang dibutuhkan adalah sistem pemilu yang cocok. Walaupun dengan sistem tersebut sudah menyederhanakan sistem kepartaian, namun masih dibutuhkan sistem yang lebih efektif untuk menyederhanakan sistem kepartaian di Indonesia seperti electoral threshold atau parliamentary threshold seperti yang sudah dianut oleh beberapa negara di dunia. 


\section{Daftar Pustaka}

A. Ahsin Thohari. 2004. Komisi Yudisial \& Reformasi Peradilan. Jakarta : ELSAM.

Agung Gunandjar Sudarsa. 2010. “ Sistem Mutipartai di Indonesia”, (http://www.djpp.depkumham.go.id/htn-dan-puu/83-sistem-multipartai-di-indonesia.html). [tanggal 4 Januari 2010]

B. Hestu Cipto Handoyo. 2003. Hukum Tata Negara, Kewarganegaraan dan Hak Asasi Manusia (Memahami Proses Konsolidasi Sistem Demokrasi di Indonesia). Yogyakarta: Universitas Atma Jaya.

Bagir Manan dan Kuntana magnar. 1993. Bunga Rampai HukumTata Negara. Bandung: Alumni

Bagir Manan. 1999. Lembaga Kepresidenan. Yogyakarta: Penerbit UII.

Budiyanto. 2003. Dasar-dasar Ilmu Tata Negara. Jakarta: PT. Gelora Aksara Pratama.

Haryanto. 1984. Partai Politik Suatu Pengantar. Yogyakarta: Penerbit Liberty.

Jimly Asshiddiqie. 2006. Kemerdekaan Berserikat, Berkumpul, dan Pembubaran Partai Politik. Jakarta: Konstitusi Press.

. 2007. Pokok-Pokok Hukum Tata Negara Indonesia Pasca Reformasi . Jakarta: Bhuana Ilmu Populer.

Moh. Kusnardi dan Harmaily ibrahim. 1976. Pengantar Hukum Tata Negara Indonesia. Jakarta: Pusat Studi HTN Fakultas Hukum UI.

Sigit Pamungkas. 2009. Sistem Pemilu. Yogyakarta: Penerbit Jurusan Ilmu Politik Fakultas Ilmu Sosial dan Ilmu Politik UGM. 